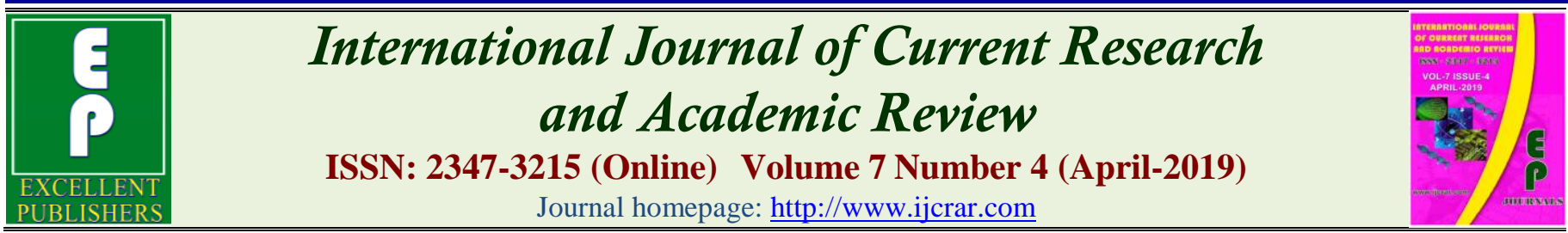

doi: https://doi.org/10.20546/ijcrar.2019.704.006

\title{
Assessing Classroom Management Experience of Local Language Teachers in Ligaba Primary School in Wolaita Zone, Ethiopia: Focus on Wolaita Language
}

\author{
Markos Mathewos Alaro* and Ayele Eyob Kenta
}

Wolaita Sodo University, Ethiopia

*Corresponding author

\begin{abstract}
The main aim of the study was to evaluate classroom management experience of local language teachers at Ligaba Primary school in Wolaita Zone of Ethiopia. The participants of the study were purposively selected six students from grade- 5 and six teachers who were teaching that grade. Two tools were used to gather data: questionnaire and interview. Both qualitative and quantitative data analysis methods were employed to obtain the results. The study clearly disclosed that there were gaps regarding teachers' time management. They did not enter the class on time and this might lead students to disturb in the class. Moreover, the study genuinely indicated that teacher did not tell the students the rules and regulations of the class and this might also seriously hampers the classroom management of teachers. It also proved that sometimes teacher interrupts teaching and go out of the class to entertain any other individuals through phone or physically. Thus, it is possible to generalize that teachers' experience in classroom management is not effective due to lack of relevant knowledge on how to manage the classroom and due to various classroom factors. Hence, it is recommended that different classroom facilities should be fulfilled for teachers and students and appropriate training should be given for the teachers by stake holders like wereda education bureau on how to manage the classroom effectively.
\end{abstract}

\section{Article Info}

Accepted: 04 March 2019

Available Online: 20 April 2019

\section{Keywords}

$\begin{array}{lr}\text { Classroom } & \text { management; } \\ \text { Experience; Local } & \text { language; } \\ \text { Wolaita language } & \end{array}$

\section{Introduction}

Classroom management is an inclusive term for a variety of teacher actions designed to facilitate teaching and learning in the classroom. Classroom management usually includes actions taken by teachers to establish order, engage students, and elicit their cooperation (Emmer and Stough, 2001). Emmer and Everston (1981) asserted that effective classroom management consisted of teacher behaviors that produced high levels of student's involvement in classroom activities, minimal amounts of student behavior that interfered with teachers or other students' work, and efficient use of instructional time. Effective teaching and learning cannot take place in poorly managed classrooms (Jones and Jones, 2012; Marzano et al., 2003). Effective classroom management strategies support and facilitate effective teaching and learning. Effective classroom management is generally based on the principle of establishing a positive classroom environment encompassing effective teacherstudent relationships (Wubbels and Brekelmans, 1999) as cited by (Korpershoek et al., 2014). 
Classroom management is essential to establish a conducive classroom and to create smooth relationship with teachers and students. Classroom management strategies are also tools that the effective classroom management strategies and classroom management programs for educational practice teachers can use to help create such an environment, ranging from activities to improve teacher-student relationships to rules to regulate student behavior (Korpershoek et al., 2014). Classroom management particularly raises key issues in language classes and is one of the biggest challenges language teachers face while they teach (Linse and Nunan, 2005).

\section{Problem statement}

Research on classroom management indicates that efficient management promotes collaboration among students, reduces discipline problems, and engages students in learning (Pane, 2010). It has also a great influence on students' academic achievement, even more than intelligence (Gettinger and Kohler, 2006). If the teacher cannot provide an environment in which teacher and students actively participate, some students will be segregated, bored, or show misbehavior (Pane, 2010). This results in failure in academic achievement for the isolated student(s) and disrupting the process of learning for the rest of the class. In this poorly managed classroom, teachers struggle to teach and students usually learn less than they should, and there is abundance of discipline issues while a well-managed classroom provides an environment in which teaching and learning can flourish (Brown, 1990).

Classroom management experience and practices of local language teachers, especially Wolaita language teachers are at threshold level. This is because teachers have little skill in managing classroom in local language context. Teachers should manage the students in classroom according to their attitude towards mother tongue. It is very difficult to supervise students in local language classroom unless teachers provide due attention to it since students do not give equal value to local language as they do for other subjects. Teachers should be friendly to students and involve them in different classroom activities and seek their cooperation in classroom so as to mitigate classroom management problems. Effective classroom management is obviously linked to teachers' ability to set an appropriate tone and gain learner respect and cooperation in class (Williams and Burden, 1997). Teachers should use alternative mechanisms to get learners collaboration and create smooth classroom atmosphere and so that classroom management might be effective. Thus, the main emphasize of this study was to assess the classroom management skills of local language (Wolaytato) teachers and then to opine possible directions to solve the problems.

The main rationale for conducting this study was that many students in different primary schools were not well disciplined and disturb in Wolaita language classroom. Based on this, the researcher desired to investigate the experience or knowledge of local language teachers in managing and handling students in classroom in local language context. According to Adeolu (2017) in classroom management, the teacher is expected to foster students' involvement in learning activities by giving prompt feedback to individual student, group and whole class, and follow-up students' feedback and attends to parents' observations on academic activities/exercises to extend learning, checks disruptive behavior to reduce disciplinary problems and stimulates students to achieve better academic performance. This implies that in classroom management, teachers are expected to perform different activities like providing feedback in individually, in group and in whole class to encourage students' participation in learning activities. Besides to this, teachers have the responsibility to manage the whole academic activities to foster learning, to examine bad behavior of students to mitigate disciplinary problems. Evertson and Weinstein as cited in Chandra, (2015) and Adeolu (2017) described classroom management as the actions taken by the teacher to create supportive environment for the academic, social and emotional learning of students.

Local language (Wolaita language) teachers also have to be well equipped with classroom management skills and classroom facilities. Local language teachers in Wolaita Zone were not effective in classroom management. For this there may be various factors like lack of giving effective training in how to manage the classroom and in teaching methods. Shortage of classroom facilities like standard classrooms with cross ventilation, lightening and moderate temperature, and well built chairs, desks, air conditioning, interactive board multimedia technology and instructional materials. All these facilities must be functionally arranged for the benefit of the students. It is part of the teacher's task of managing the classroom to devise ways of making the best use of the learning facilities by grouping the learners for different activities and interacting with them to ensure 
optimal utilization of the facilities to achieve the desired learning outcome.

Several researches were carried out in classroom management. But, almost no research were done specifically on classroom management experiences of local language teachers (Wolaita Language) and this study assumed to fill this gap. Thus, this study was conducted to assess the classroom management experiences of local language (Wolaita language) teachers in Ligaba primary schools of Wolaita zone.

\section{Research questions}

To what extent are teachers experienced to manage local language classroom during teaching learning process?

What are hindrances of classroom management in local language classroom?

What are techniques of managing classroom effectively when teaching local languages?

\section{Objectives of the Study}

The main objective of the study was to assess classroom management experiences of local language teachers (Wolaita language) in Ligaba primary schools of Wolaita Zone. In relation to general objective, the specific objectives are the following:

To judge the extent of teachers' experience to manage local language classroom?

To identify hindrances of classroom management when teaching local/ Wolaita languages.

To suggest techniques of managing classroom when teaching Wolaita /local language.

\section{Materials and Methods}

\section{Research design}

The main focus of this study was to assess classroom management experiences of local language teachers in Ligaba primary school of Wolaita zone. Hence, in order to get relevant information, the researcher used both qualitative and quantitative research design. The reason for using these research designs was that they were quite convenient to assess class room management experiences of local language teachers and the nature of the research by itself also allowed using them.

\section{Research Setting}

The research was conducted in Wolaita Zone which is one of thirteen zones found in SNNPR, Ethiopia. It has twelve weredas and three administrative towns. Among these, one town administration was purposively selected. The reason for selecting this place was that it might be suitable for the research to gain sufficient information from the areas as it is nearer to the researcher's Work place.

\section{Research Population}

The research was conducted in primary school of Wolaita Sodo town administration. The populations for this study was one primary school i.e. grade- 5 Ligaba primary school from Sodo city administration. From this school, 6 students and 6 Wolaita Language teachers were selected by using purposive sampling technique for study as sample size from grade-5 and these were the research population. The purposive sampling was essential for the researcher to find those who can give pertinent data. Thus, the total number of the population was 12 .

\section{Sample size and sampling technique}

The sample of the study was decided based on the purpose of the study. The total population size of the study was 12 . In order to get this sample, the researcher used purposive sampling techniques for all population.

The reason for using purposive sampling was to participate the research subjects who could provide rich information to the study. One primary school was selected purposively from Sodo town administration by taking in to account its accessibility for the researcher to reach the area. In line with this, 6 students and 6 Wolaita language teachers were purposely selected. Thus, only grades 5 students were selected using purposive sampling so as to get those students who could offer ample data in the research project. From the selected school, two sections were selected by using purposive sampling technique. This was based on information about the students that were given by the school principals so as to get adequate information. From each section, 3 students were selected using purposive sampling techniques. Hence, 6 students were selected so that totally $6(3 \times 2)$ students were participated in the study and 6 Wolayta Language teachers were selected purposely from the selected school. Hence, the total sample was 12 . 


\section{Tools for data collection}

Two tools were used to collect data for this study. These were interview and questionnaire.

\section{Data analysis}

In this study, both qualitative and quantitative method of data analysis was employed. This was because the qualitative and quantitative data were gathered from teachers and students of the selected sections. The data gathered through both questionnaire and interview was analyzed both qualitatively and quantitatively. Thus, the researcher first analyzed the questionnaires and then compared its result with the analysis of interview. The researcher integrated the data by bringing the interview answers of teachers to the questionnaire data so as to create the holistic picture of the study. Hence, the data was analyzed by comparing the results of the questionnaire with the interview results.

\section{Results and Discussions}

This chapter included discussion of the results obtained from the research subjects through interview and discussion of information found from a likert scale questionnaire.

As can be seen from the above table 1 item 1.1, majority of the respondents about $83.3 \%$ replied as they strongly disagree regarding the idea which says teacher comes to the classroom on time before students and about 16.6.\% of them replied that they do not decide it and no one selected other options in table.

The data found from the interview is relatively different from questionnaire. Many of the respondents said that teachers attend the class before students. Let us see some of the respondents. In this school teachers enter the class on time. Regarding this there is no problem in this school. Teachers know their responsibility to do so (T1, T3, T5 and T6). Sometimes teachers do not enter the classroom on time. But when they miss the class the compensate it by makeup class (T2 and T4). From this interview data we can see that many teachers replied as they enter the class on time and at the same time some answered that they do not entered on time. Therefore, based on the results of interview and questionnaire, we can generalize that there were gaps regarding teachers' time management when they enter the class.
As shown in table 1 , item 1.2, many of the participants (33.3\%) strongly agreed that teachers identify disturbing students in class and advise them and $16.6 \%$ of the respondents did not decide their reply. Again about a lot of students (33.3\%) answered that they disagreed on statement which says teachers identify disturbing students in class and advise them. The remaining 16.6\% responded that they strongly agreed on the same statement.

The interview data indicated almost the same result. Some of the respondents said that teachers identify the disturbing students and advice them and some teachers answered opposite to it. Therefore, based on all this we can assume that teachers efforts to identifying disturbing students and advising them was too less and it needs further work by teachers to improve it.

As we can see from table 1 item 1.3 , the majority respondents $(50 \%)$ strongly agreed on the statement that says teacher walks around students and facilitates, encourages, supports their learning and supervises them and $33.3 \%$ of them replied as they agreed on the same statement. On the other hand, only $16.6 \%$ of the respondents disagreed on that statement and no one replied other options. The interview data also shows almost all teachers walk around and supervises and encourages students in the classroom.

Based on the above data found from the interview and questionnaire, we can assume that teachers walk around the students and encourage and motivate them and this is positively seen in study.

As shown in table 1 , item 1.4 , about $16.6 \%$ strongly agreed that teacher gives opportunity for students to learn each other in Wolaita language classroom and again 16.6. \% said that they agreed in the above statement. Again the same number $(16.6 \%)$ responded similarly. On the other hand, the majority of the respondents about 33.3. \% disagreed on the same statement which says teacher gives opportunity for students to learn each other in Wolaita language classroom and $16.6 \%$ strongly disagreed this statement. The interview data also indicated relatively different answers. Teachers play their best, but they are not doing it fully $(A T)$. The interview also shows as teacher do not give chance for the students. Thus, based on the results of interview and questionnaire we can guess that teachers do not give opportunity for the students to learn each other. 
In table 1 , item 1.5 , a few students i.e. $16.6 \%$ strongly agreed on the statement that teacher knows the name of all students in classroom and similarly $16.6 \%$ of the respondents did not decide their answer. However, a lot of students $(50 \%)$ disagreed on the same idea. Again, $16.6 \%$ strongly disagreed on that suggestion. The information from the interview also demonstrated almost the same result. It is difficult to say that all teachers know the name of all students in class. Only few teachers know the name of few some students (AT).

Therefore, based on the data found from interview and questionnaire one can estimate that teachers do not know the name of all students in class and this by itself impedes classroom management of teachers as knowing students' name has its own contribution to control the students in class effectively.

As indicated in table 1, item 1.6, the majority of the participants about 50\% assured that teacher establishes a good relationship with the students in class and 16.6\% did not decide their answer. However, about $33.3 \%$ of the respondents disagreed on the same statement. The interview data also proved the information found from questionnaire. The teacher has a positive relation with the students. They work together and participate in meeting when necessary. Thus, based on the results of interview and questionnaire, it is possible to conclude that teachers and students have a good relationship.

As it is demonstrated in table 1 item 1.7 , few students about $16.6 \%$ strongly agreed that teacher tells students the rules and regulations of the class and $16.6 \%$ do not decide their answer. However, the majority of the respondents about $33.3 \%$ disagreed on the statement that teacher tells students the rules and regulations of the class. Again 33.3.\% strongly disagreed on the same idea. The interview data also supported the questionnaire. The rules and the regulations of the school is told to students in school level, but the rules and regulations of the classroom was not told to the students(AT). Here the interview data by itself shows that classroom rules are not told to the students. Based on the data found from interview and questionnaire, one can assume that teacher did not tell the students the rules and regulations of the class.

As clearly indicated in above table 1 item 1.8, lots of respondents $(50 \%)$ strongly agreed on the statement which says teacher takes students' attendance at the end of class and few participants about $16.6 \%$ normally agreed on the same statement. Again, $33.3 \%$ of the respondents strongly disagreed on this item. This is also almost the same as the answer given by teachers' in interview. It is usual for the teachers to take students attendance at the end of the class. If we do not do so, students may not enter the class and follow the lesson properly. Based on the results of interview and questionnaire we can conclude that the teacher takes students' attendance at the end of the class.

As depicted in table 1, item 1.9, many respondents i.e. about $33.3 \%$ strongly agreed on the statement which says teacher gives effective feed back to students' questions and $16.6 \%$ quite agreed in this item. Again, $16.6 \%$ of the respondents did not decide their option. On the other hand, $33.3 \%$ of the respondents disagreed on the same idea. The results of interview show different answers. For example, some teachers said that teacher gives effective feedback to students and some said that they did not do this. As far as I know almost all teachers give feed for the students whenever they raise questions (T3 and T4). It is difficult to say that all teachers give feed back to students. Many teacher said that time is over and leave the class rather than giving effective feedback for the students (T1, T2, T5 and T6). Here we can understand that teachers gave different answers in interview. Therefore, based on this information we can easily guess that some teachers did not give feedback to students questions this affects the process of classroom management.

As one can see in table 1 item 1.10, majority of the respondents about $50 \%$ replied as they strongly agreed on the item which says sometimes teacher interrupts teaching and go out of the class to entertain any other individuals through phone or physically and $16.6 \%$ of the respondents did not decide their answer. Again, 33.3\% of the respondents strongly disagreed on the same statement. The interview data is slightly different from the questionnaire. Teacher sometimes leaves the class when they encounter special case and they will not DO. This carelessly (T5 and T6). Of course, some teachers leave the class when teaching students with no sufficient reason and due to this some students even leave the class following the teacher and I think this needs more effort to solve (T2, T4). The interview data clearly shows that teachers leave the class when teaching students. Thus, the data found from both interview and questionnaire we can estimate that sometimes teacher interrupts teaching and go out of the class to entertain any other individuals through phone or physically and this affects the classroom management. 
As we can see from the above table 1, item 1.11, 33.3\% of the respondents strongly agreed on the statement that says teacher comes to the class with all essential instructional materials and $16.6 \%$ moderately agreed on similar item. However, the majority of the participants about $50 \%$ disagreed on the statement that teachers comes to the class with all essential instructional materials. The interview data indicated relatively different results. We enter the class with all the necessary instructional materials which are available in school. Most of the time we fully use all instructional materials for teaching purpose. Sometimes we only use few of them when all materials are not available in school(AP).This interview data clearly shows that teachers use all the available materials with the exception of its shortage.

Thus, based on formation found from both tools one can summarize that teachers' use of all teaching materials may not be convincing and needs more work on the issues. Teachers replied as they use all teaching materials and students answers opposed it. This shows that it is important for teachers to revisit their use of material.

As demonstrated in table 1 item 1.12, 33.3\% of the research subjects strongly agreed that teacher regularly attends the class and uses all his time effectively and $16.6 \%$ of the participants did not decide the answer. However, the majority respondents (50\%) strongly disagreed on the same statement. The interview data also shows almost the same result. Actually, it is impossible to say that all teachers regularly attend the class and use their time effectively. Some teachers tied up in social issues and sometimes miss the class(AP). Therefore, based on these data, we can estimate that teacher does not regularly attend the class all the time effectively and this can be one of the problems that influence classroom management.

As can be seen from the above table 2, item 2.1, 16.6\% of the research subjects quite agreed that on the statement that says there are no sufficient spaces between chairs and tables for the teachers to move and manage the class. However, majority of the respondents about 83.3.\% disagreed for the same item and no one selected other items. The interview data also proved the data found from the questionnaire. It is fair to place 30 students in each class, but there is almost 90 students in each classroom and it is beyond the capacity of teachers to manage effectively. There is no sufficient space between chairs, tables and desks for teachers to move freely. The class is too crowded and due to that there is almost no free space (AP).

Based on the above data collected by both tools, one can assume that there is no sufficient space between chairs and tables for the teachers to move and manage the class.

In above table 2, item 2.2, few participants about 16.6.\% relatively agreed on the statement which says the school has no strong rules regarding students' duties and rights. However, about $50 \%$ of the respondents did not decide their response and $1.6 .6 \%$ of the respondents respectively strongly disagreed and disagreed on the same statement. The interview data also almost approved the above the questionnaire. The school tells the rules and regulation for the students at school level, but the classroom rules and regulation is not told to students by the teachers who teach students. Thus, based on the data found from the tools, it is possible to conclude that the rules and regulations of the class may not be told to students effectively and this is by itself hinders class room management.

In table 2, item 2.3, majority of the research subjects $(67 \%)$ strongly agreed that the classroom is too crowded to manage the classroom and about $16.6 \%$ did not decide their answer. Again, $16.6 \%$ strongly disagreed on the same statement. The interview data also clearly indicated that the classroom is too crowded to manage the students. The number of the students is very high and the classroom is narrow and this highly affects classroom management. The class size is out of the control (AP). Therefore, based on the interview and questionnaire, we can guess that the classroom is too crowded to manage the class and this impedes classroom management.

As can be seen from table 2, item 2.4, a lot of the respondents about $33.3 \%$ strongly agree on the statement which says there are no adequate seats for the students in class and $33.3 \%$ did not decide their answer. Next to this about $16.6 \%$ of the respondents disagreed on the same statement and $16.6 \%$ strongly disagreed on that item. The interview data also indicated almost the same result. There is really shortage of seats in the classroom.

The seat is not sufficient for the students. This also shows that there is shortage of seats in the class. Based on the above data found from both tools, it is possible to generalize that there is no sufficient seats in the classroom and this by itself affects classroom management. 
Table.1 The extent of teachers experience to manage local language classroom during teaching learning process?

\begin{tabular}{|c|c|c|c|c|c|c|}
\hline \multirow[t]{2}{*}{ Sn } & \multirow[t]{2}{*}{ Items } & SA & $\mathrm{A}$ & UD & $\mathrm{D}$ & SD \\
\hline & & $\begin{array}{l}\mathrm{f} \\
\%\end{array}$ & f & f & f & f \\
\hline 1.1 & Teacher comes to the classroom on time before students & - & - & $\begin{array}{l}1 \\
16.6\end{array}$ & - & $\begin{array}{l}5 \\
83.3\end{array}$ \\
\hline 1.2 & $\begin{array}{l}\text { Teacher identify disturbing students in class and advise } \\
\text { them }\end{array}$ & $\begin{array}{l}2 \\
33.3\end{array}$ & - & $\begin{array}{l}1 \\
16.6\end{array}$ & $\begin{array}{l}2 \\
33.3\end{array}$ & $\begin{array}{l}1 \\
16.6\end{array}$ \\
\hline 1.3 & $\begin{array}{l}\text { Teacher walks around students and facilitates, } \\
\text { encourages, supports their learning and supervises them. }\end{array}$ & $\begin{array}{l}3 \\
50\end{array}$ & $\begin{array}{l}2 \\
33.3\end{array}$ & - & $\begin{array}{l}1 \\
16.6\end{array}$ & - \\
\hline 1.4 & $\begin{array}{l}\text { Teacher gives opportunity for students to learn each } \\
\text { other }\end{array}$ & $\begin{array}{l}1 \\
16.6\end{array}$ & $\begin{array}{l}1 \\
16.6\end{array}$ & $\begin{array}{l}1 \\
16.6\end{array}$ & $\begin{array}{l}2 \\
33.3\end{array}$ & $\begin{array}{l}1 \\
16.6\end{array}$ \\
\hline 1.5 & Teacher knows the name of all students in classroom & $\begin{array}{l}1 \\
16.6\end{array}$ & - & $\begin{array}{l}1 \\
16.6\end{array}$ & $\begin{array}{l}3 \\
50\end{array}$ & $\begin{array}{l}1 \\
16.6\end{array}$ \\
\hline 1.6 & $\begin{array}{l}\text { Teacher establishes a good relationship with the students } \\
\text { in class }\end{array}$ & $\begin{array}{l}3 \\
50\end{array}$ & - & $\begin{array}{l}1 \\
16.6\end{array}$ & $\begin{array}{l}2 \\
33.3\end{array}$ & - \\
\hline 1.7 & $\begin{array}{l}\text { Teacher tells students the rules and regulations of the } \\
\text { class }\end{array}$ & $\begin{array}{l}1 \\
16.6\end{array}$ & - & $\begin{array}{l}1 \\
16.6\end{array}$ & $\begin{array}{l}2 \\
33.3\end{array}$ & $\begin{array}{l}2 \\
33.3\end{array}$ \\
\hline 1.8 & The teacher takes students' attendance at the end of class & $\begin{array}{l}3 \\
50\end{array}$ & $\begin{array}{l}1 \\
16.6 \\
\end{array}$ & - & - & $\begin{array}{l}2 \\
33.3 \\
\end{array}$ \\
\hline 1.9 & Teacher gives effective feed back to students' questions & $\begin{array}{l}2 \\
33.3\end{array}$ & $\begin{array}{l}1 \\
16.6\end{array}$ & $\begin{array}{l}1 \\
16.6\end{array}$ & $\begin{array}{l}2 \\
33.3\end{array}$ & - \\
\hline 1.10 & $\begin{array}{l}\text { Sometimes teacher interrupts teaching and go out of the } \\
\text { class to entertain any other individuals through phone or } \\
\text { physically. }\end{array}$ & $\begin{array}{l}3 \\
50\end{array}$ & - & $\begin{array}{l}1 \\
16.6\end{array}$ & - & $\begin{array}{l}2 \\
33.3\end{array}$ \\
\hline 1.11 & $\begin{array}{l}\text { Teacher comes to the class with all essential instructional } \\
\text { materials. }\end{array}$ & $\begin{array}{l}2 \\
33.3\end{array}$ & $\begin{array}{l}1 \\
16.6\end{array}$ & - & $\begin{array}{l}3 \\
50\end{array}$ & - \\
\hline 1.12 & $\begin{array}{l}\text { Teacher regularly attends the class and uses all his time } \\
\text { effectively. }\end{array}$ & - & $\begin{array}{l}2 \\
33\end{array}$ & $\begin{array}{l}1 \\
16.6\end{array}$ & - & $\begin{array}{l}3 \\
50\end{array}$ \\
\hline
\end{tabular}

$\mathrm{f}=$ frequency $\%=$ percentage SA: Strongly Agree $=5$ AG: Agree $=4$ UD: Undecided=3

DS: Disagree=2 SD: Strongly Disagree $=1$ 
Table.2 Hindrances of classroom management in local language classroom

\begin{tabular}{|c|c|c|c|c|c|c|}
\hline \multirow[t]{2}{*}{$\mathrm{Sn}$} & \multirow[t]{2}{*}{ Items } & SA & $\mathrm{A}$ & UD & $\mathrm{D}$ & SD \\
\hline & & f & f & f & f & f \\
\hline 2.1 & $\begin{array}{l}\text { There is no sufficient spaces between chairs and tables for } \\
\text { the teachers to move and manage the class }\end{array}$ & - & $\begin{array}{l}1 \\
16.6\end{array}$ & - & $\begin{array}{l}5 \\
83.3\end{array}$ & - \\
\hline 2.2 & $\begin{array}{l}\text { The school has no strong rules regarding students' duties } \\
\text { and rights }\end{array}$ & - & $\begin{array}{l}1 \\
16.6\end{array}$ & $\begin{array}{l}3 \\
50\end{array}$ & $\begin{array}{l}1 \\
16.6\end{array}$ & $\begin{array}{l}1 \\
16.6\end{array}$ \\
\hline 2.3 & The classroom is too crowded to manage & $\begin{array}{l}4 \\
67\end{array}$ & - & $\begin{array}{l}1 \\
16.6\end{array}$ & - & $\begin{array}{l}1 \\
16.6\end{array}$ \\
\hline 2.4 & There is no adequate seats for the students in class & $\begin{array}{l}2 \\
33.3\end{array}$ & - & $\begin{array}{l}2 \\
33.3\end{array}$ & $\begin{array}{l}1 \\
16.6\end{array}$ & $\begin{array}{l}1 \\
16.6\end{array}$ \\
\hline 2.5 & $\begin{array}{l}\text { The school does not take legal measures on repeatedly } \\
\text { misbehaved students }\end{array}$ & - & $\begin{array}{l}2 \\
33.3\end{array}$ & $\begin{array}{l}2 \\
33.3\end{array}$ & $\begin{array}{l}1 \\
16.6\end{array}$ & $\begin{array}{l}1 \\
16.6\end{array}$ \\
\hline 2.6 & $\begin{array}{l}\text { The classroom is not conducive to implement effective } \\
\text { management. }\end{array}$ & - & $\begin{array}{l}2 \\
33.3\end{array}$ & - & $\begin{array}{l}4 \\
67\end{array}$ & - \\
\hline 2.7 & Shortage of sufficient learning materials for students & $\begin{array}{l}2 \\
33.3\end{array}$ & - & $\begin{array}{l}2 \\
33.3\end{array}$ & $\begin{array}{l}1 \\
16.6\end{array}$ & $\begin{array}{l}1 \\
16.6\end{array}$ \\
\hline 2.8 & $\begin{array}{l}\text { Lack of giving training for the teachers on how to manage } \\
\text { the class effectively }\end{array}$ & - & $\begin{array}{l}3 \\
50\end{array}$ & $\begin{array}{l}2 \\
33.3\end{array}$ & $\begin{array}{l}1 \\
16.6\end{array}$ & - \\
\hline
\end{tabular}

$\mathrm{f}=$ frequency $\%=$ percentage SA: Strongly Agree =5 AG: Agree =4 UD: Undecided=3

DS: Disagree $=2$ SD: Strongly Disagree $=1$

As shown in table 2, item 2.5, lots of the respondents $(33.3 \%)$ agreed that the school does not take legal measures on repeatedly misbehaved students and $33.3 \%$ again did not decide their answer. Next to this, $16.6 \%$ disagreed on the same statement and $16.6 \%$ again strongly disagreed on it. The interview data shows relatively different result. We advise students when they got misbehaved and if they continue misbehaving we continue to take them to school administration.. Therefore, based on the above data, we can conclude that the school may take legal measures on misbehaved students and this should be encouraged.

As indicated in table 2 item 2.6, about $33.3 \%$ of the respondents agreed that he classroom is not conducive to implement effective management. However, the majority of the respondents about $67 \%$ strongly disagreed on the similar statement and no one chosen other options. The interview data by itself proved this. The classroom is not conducive for classroom management (AP). Based on the data found from both tools it is possible to guess that the classroom is not conducive for the classroom management.

As demonstrated in table 2, item 2.7, 33.3\% of the respondents strongly agreed on the statement which says shortage of sufficient learning materials for students and again $33.3 \%$ did not decide their answer. Next to this, $16.6 \%$ of the respondents disagreed on this statement and $16.6 \%$ strongly disagreed on that statement. The 
interview data proved also this. In our school there is shortage of text book and this is because the number of the students too high and the text book is not less. Therefore based on this information, it is possible to conclude that shortage of sufficient learning materials for students and this also affects the classroom management of teachers.

In table 2, item 2.8, the majority of the respondents $(50 \%)$ agreed that lack of giving training for the teachers on how to manage the class effectively and $33.3 \%$ did not decide their answer. Again, 16.6\% of the respondents strongly disagreed that lack of giving training for the teachers on how to manage the classroom effectively affects the classroom management. All respondents in interview agreed that they did not take training in how to manage the classroom effectively. Therefore, based on these data we can conclude that teachers were not given training on how to manage the class effectively and this also one of factors that affect the classroom management.

\section{Conclusions and Recommendations}

\section{Conclusions}

In line with the findings of the study, the following conclusions were made.

The study clearly disclosed that there were gaps regarding teachers' time management. They did not enter the class on time and this leads students to disturb in the class and so that affects classroom management.

The research findings also show that teachers efforts to identifying disturbing students and advising them was too less and it needs further work by teachers to improve it.

The study indicated that teachers walk around the students and encourage and motivate them and this should be encouraged because it is what teachers were implementing in Wolaita language classroom.

The findings also demonstrated that teachers did not give chance for the students to learn each other in Wolaita language classroom and this implies that studentcentered teaching was not carried out. It also depicted that teachers do not know the name of all students in the class and this by itself impedes classroom management as knowing students' name has its own contribution to control the students in class.

Moreover, the study genuinely indicated that teacher did not tell the students the rules and regulations of the class and this might also seriously hampers the classroom management of teachers since many student misbehaved in class due to lack of being informed about school regulations and rules.

The findings obviously confirmed that the teacher takes students' attendance at the end of the class and this also essential to manage the disturbing students in the class.

The research proved that some teachers did not give feedback to students' questions and this may also affect the process of classroom management.

As can be seen from the findings, sometimes teacher interrupts teaching and go out of the class to entertain any other individuals through phone or physically and this affects the classroom management.

The study indicated that teachers' use of all teaching materials may not be convincing and needs more work on the issue. Teachers replied as they use all teaching materials and students answers opposed it. This shows that it is important for teachers to revisit their use of material.

The study also approved that teacher do not regularly attend the class and all the time effectively and this can be one of the problems that influence classroom management.

The study indicated that there is no sufficient spaces between chairs and tables for the teachers to move and manage the class.

It also clearly shows that there is no sufficient spaces between chairs and tables for the teachers to move and manage the class.

The study disclosed that the classroom is too crowded to manage the class and this impedes classroom management. It also indicated that there is no sufficient seats in the classroom and this by itself affects classroom management.

The research approved that that the school may take legal measures on misbehaved students and this should be encouraged. It also proved that that the classroom is not conducive for the classroom management.

It is possible to see from the research findings that shortage of sufficient learning materials for students and this also affects the classroom management of teachers. One can also see that teachers were not given training on how to manage the class effectively and this also one of factors that affect the classroom management.

Thus, it is possible to generalize that teachers' experience in classroom management is not effective due to lack of relevant knowledge on how to manage the classroom and various factors related to classroom. 


\section{Recommendations}

According to the conclusions and discussions made above, the following recommendations were made.

There is a gap regarding time management by the teachers. Therefore, teachers should enter the class on time and regarding this issue, appropriate supervision ought to be done by the concerned body like school principals on teachers; Otherwise, it might be difficult to solve classroom management problem.

Teacher should identify frequently disturbing students in the class and provide due advices and support to them to improve their behavior and they should also offer opportunity for the students to learn each other in the classroom. This may help teachers to mitigate problems related to classroom management.

It is essential for the teachers to know the name of all students in the classroom as it helps teachers to call their name when they starts to disturb and when teachers call their name, they may be ashamed and stop disturbing in the classroom.

Teachers should tell the students the rules and regulation of the class since many students misbehave in classroom due to lack of knowledge regarding those rules and regulations. Similarly, teachers ought to give feedback for questions raised by the students on time and this may help classroom management process.

With the exception of especial case, teachers should not leave the class when teaching the students and switch off their cell phones. This is because when teachers leave the classroom, students may start to disturb and this may affect teaching learning process of the students and may lead to commotion in the classroom.

Teachers should revisit their teaching materials and use all teaching materials use full for the classroom. Teachers teaching should be attractive with all teaching materials.

As much as possible teachers should attend the class regularly and this can reduce classroom management problem. At the same time, there should be sufficient spaces between chairs and tables and for that all stakeholders like wereda education bureau and school principals should play their own role to solve the problems related it.

The concerned bodies should revisit the class size because the classroom is too crowded for the teachers to manage the classroom and similarly, there should be adequate seats in the classroom.
The school should procedurally and openly take legal(administrative) measures on disturbing students so as to use it as a caution for other students.

The schools and wereda education bureau should provide sufficient teaching materials for teachers.

Teachers should be given training on how to manage the classroom as they have no sufficient knowledge pertaining to it.

\section{References}

Adeolu (1917). Teachers' Classroom management and Quality Assurance of Students' Learning Outcome in Secondary Schools in Ondo State, Nigeria.

Brown, H. D. (1990). $M$ and Ms For Language Classrooms? Another Look At Motivation. In J.E. Alatis (Ed.), Georgetown University Round Table On Language And Linguistics (Pp. 383-393). Washington, DC: Georgetown University Press.

Chandra, S. (2015). Classroom management for effective teaching. International Journal of Education and Psychological Research, 4(4), 13-15.

Fredson (2015). The Relationship between Teachers and Students in the Classroom: Communicative Language Teaching Approach and Cooperative Learning Strategy to Improve Learning

Gettinger, M., and Kohler, K. M. (2006). Processoutcome approaches to classroom management and effective teaching. In C. M. Evertson, and C. S. Weinstein (Eds.), Handbook of classroom management: Research, practice, and contemporary issues (pp. 73-96). Mahwah, NJ: Lawrence Erlbaum.

Jones, V.F. and Jones, L. S. (2012). Comprehensive classroom management, creating communities of support and solving problems (10th ed). Upper Saddle River, NJ: Pearson.

Korpershoek et al., 2014. Effective classroom management strategies and classroom management programs for educational practice.

Linse, C., and Nunan, D. (2005). Practical English language teaching. US: McGraw-Hill.

Marzano, R. J., Marzano, J. S., and Pickering, D. J. (2003). Classroom management that works. Research-based strategies for every teacher. Alexandria, VA: Association for Supervision and Curriculum Development (ASCD).

Pane, D. (2010). Viewing classroom discipline as negotiable social interaction: A communities of practice perspective. Teaching and Teacher Education, 26, 87-97.

Wallace, M. J. 1991. Training foreign Language 
Teachers: Reflective Approach. Cambridge: CUP. Williams, M., and Burden, R. (1997). Psychology for language teachers: A social constructivist approach. Cambridge: Cambridge University Press.

\section{How to cite this article:}

Markos Mathewos Alaro and Ayele Eyob Kenta. 2019. Assessing Classroom Management Experience of Local Language Teachers in Ligaba Primary School in Wolaita Zone, Ethiopia: Focus on Wolaita Language. Int.J.Curr.Res.Aca.Rev. 7(4), 41-51. doi: https://doi.org/10.20546/ijcrar.2019.704.006 